\title{
Profesor Franciszek Pepłowski (1921-2009)
}

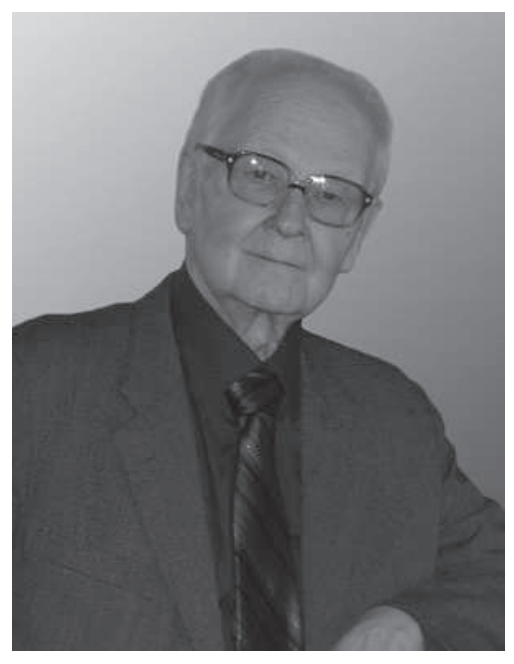

przez większą część swojego życia. Swoją naukową drogę rozpoczął również w Toruniu, gdzie 19 grudnia 1949 r. uzyskał na Uniwersytecie Mikołaja Kopernika tytuł magistra filozofii w zakresie filologii polskiej na Wydziale Humanistycznym. Zarówno praca magisterska pt. Uwagi nad językiem Stanisława Trembeckiego, jak i cząstkowe egzaminy magisterskie zostały ocenione bardzo dobrze. Młody Franciszek Pepłowski wykazał się już na egzaminie magisterskim, który obejmował szeroki zakres materiału, dogłębną i rzetelną wiedzą, uzyskując najwyższe noty z przedmiotów, takich jak: gramatyka opisowa współczesnej polszczyzny, gramatyka opisowa języka staro-cerkiewno-słowiańskiego, podstawowe wiadomości z historycznej gramatyki języka polskiego i dialektologii, historia literatury polskiej wraz z podstawowymi wiadomościami z teorii literatury, poetyki i stylistyki, historia polityczna, ustrojowa i kulturalna Polski. 
Jeszcze w trakcie studiów podjął pracę na UMK, gdzie od 1 września 1947 do 30 listopada 1949 r. pełnił funkcję zastępcy asystenta w Katedrze Języka Polskiego. Później kilkakrotnie pracował na etacie naukowym w tejże uczelni w Instytucie Filologii Polskiej na Wydziale Humanistycznym (dzisiejszy Wydział Filologiczny) w latach: 1957-1961, 1973-1986 oraz 1989-1991, a w latach 1992/93 na ćwierć etatu. Również później nie zerwał z uniwersytecką dydaktyką, znajdując zatrudnienie w Wyższej Szkole Humanistyczno-Ekonomicznej we Włocławku. Wykładał na tamtejszej filologii polskiej Wydziału Humanistycznego (późniejszy Wydział Nauk Społecznych i Technicznych) od 15 marca 2001 do 30 listopada 2006 r. Prowadził ćwiczenia i wykłady z gramatyki opisowej języka polskiego, gramatyki historycznej, leksykografii i leksykologii oraz wykłady monograficzne. Był promotorem licznych prac magisterskich. Jako wykładowca udzielał się również poza granicami kraju; w latach 1987-1989 brał udział w seminarium slawistycznym uniwersytetu w Getyndze, gdzie wygłosił sześć wykładów dla uczestników Gütinger Polonisten Kolloquium. Ciekawa i owocna inicjatywa naukowa zakończyła się, niestety, wraz ze śmiercią organizatora seminarium.

Dziełem życia, a jednocześnie największą pasją - nie tylko naukową - pozostał dla Profesora Słownik polszczyzny XVI wieku. Swoją przygodę leksykograficzną rozpoczął 1 stycznia 1950 r., kiedy to został zatrudniony w Instytucie Badań Literackich PAN w zespole leksykograficznym w Toruniu. Od tego czasu do 31 grudnia 1959 r. był sekretarzem redakcji Stownika Adama Mickiewicza, jednocześnie włączył się do prac nad Słownikiem polszczyzny XVI wieku, dołączając do utworzonej w 1949 roku z inicjatywy prof. Marii Renaty Mayenowej pracowni toruńskiej, mieszczącej się do dziś przy ul. Piekary 8. Wspólna praca nad sztandarowym dziełem Profesora rozpoczęła się 2 stycznia 1950 r. Wkrótce, od 1 kwietnia 1951 r. zatrudniony został na etacie asystenta, później starszego asystenta. Od I tomu słownika był sekretarzem redakcji, względy pozanaukowe zadecydowały, iż Profesor Mayenowa nie była tytułowana jego redaktorem naczelnym. Zmiana nastapiła od 1971 r., kiedy to w tomie V jako redaktora naczelnego wymieniono Marię Renatę Mayenową, Franciszka Pepłowskiego - jako zastępcę redaktora naczelnego. Honorując zasługi Profesor Mayenowej, Profesor Pepłowski zadecydował, że Jego nazwisko nadal, nawet po śmierci Profesor Mayenowej w 1988 r., podpisane będzie pod jej nazwiskiem, jak dotąd - jako zastępcy redaktora naczelnego. Ostatni wydany za życia Profesora tom XXXII (2004) słownika także wskazuje Marię Renatę Mayenową jako redaktora naczelnego. 
Naukowa droga Franciszka Pepłowskiego związana była na wszystkich etapach z Instytutem Badań Literackich PAN. Tu uzyskał 11 listopada 1959 r. stopień doktora w zakresie językoznawstwa polskiego, przedstawiając pracę pt. Stownictwo i frazeologia publicystyki polskiej okresu oświecenia i romantyzmu. W związku z tym od 1 października 1965 r. objął stanowisko adiunkta (wcześniej, od 10 stycznia 1955 nadany miał tytuł naukowy adiunkta). 1 marca 1972 r. po uzyskaniu tytułu doktora habilitowanego nauk humanistycznych w zakresie językoznawstwa polskiego (12 czerwca 1971) objął stanowisko samodzielnego pracownika naukowo-badawczego i aż do przejścia na emeryturę, czyli do 31 grudnia 1991, był kierownikiem pracowni. Nadal jednak kierował naukowo projektem, nawet wówczas, gdy Jego zatrudnienie na pół etatu wygasło w maju 1993 r. W kolejnych etapach pracy naukowej uzyskał 16 października 1985 r. tytuł profesora nadzwyczajnego, a 1 maja 1991 - profesora zwyczajnego.

Choć praca nad rokrocznie wydawanymi tomami słownika zabierała Profesorowi większość czasu, wypromował dwie prace doktorskie, a w dwu kolejnych był recenzentem. Ponadto był recenzentem przy awansie do tytułu profesora zwyczajnego, a także recenzentem w przewodach habilitacyjnych. W miarę skromnych możliwości czasowych włączał się w życie naukowe i kulturalne. Był członkiem Towarzystwa Naukowego w Toruniu, Polskiego Towarzystwa Językoznawczego oraz Towarzystwa Miłośników Języka Polskiego. Czynnie uczestniczył w obchodach Roku Samuela Bogumiła Lindego w 2007 r., kiedy to przypadła 160 rocznica śmierci wielkiego leksykografa i 200 rocznica ukazania się pierwszego tomu jego Słownika języka polskiego. Z dużym zaangażowaniem propagował Słownik polszczyzny XVI wieku, również wśród młodzieży uczącej się. Przeprowadził kilka zajęć dla członków Międzyszkolnego Koła Polonistów działającego przy dawnym Wydziale Humanistycznym UMK. Zawsze chętnie służył swoją szeroką wiedzą badaczom z różnych dziedzin, którzy w pracowni zbierali materiały do swojej pracy, językoznawcom, historykom literatury, slawistom, germanistom, historykom.

Wszechstronne, nie ograniczone tylko do zagadnień językoznawczych, zainteresowania Franciszka Pepłowskiego znalazły odbicie w Jego publikacjach. Profesor jest autorem 6 książek. Jego napisane we współpracy ze Stefanem Hrabcem Wiadomości o autorach i dziełach cytowanych $w$ stowniku Lindego (1963) nadal stanowią podstawowe źródło wiedzy o tekstach wykorzystanych przez XIX-wiecznego leksykografa, zaś Zasady wydawania tekstów staropolskich (1955), powstałe jako rezultat zainicjowanej przez Marię Renatę Mayenową 
wspólnej pracy Profesora i wielu wybitnych ludzi nauki - Konrada Górskiego, Władysława Kuraszkiewicza, Stefana Saskiego, Witolda Taszyckiego, Stanisława Urbańczyka, Stefana Wierczyńskiego, Jerzego Woronczaka - to cenna instrukcja, obejmująca w sposób systematyczny i wyczerpujący wskazane zagadnienie. W 1974 r. wraz z Januszem Małłkiem opracował wydanie Historyji żałosnej a straszliwej o Franciszku Spierze oraz Ortografiji polskiej Stanisława Murzynowskiego (1528-1553), uzupełnione i wydane po raz drugi w 1986 r. Poza tym jest autorem opracowań: Odczasownikowe nazwy wykonawców czynności w polszczyźnie XVI wieku (1974), które stanowiło Jego rozprawę habilitacyjna, oraz Pożyczki niemieckie w „Nomenklatorze” Piotra Artomiusza z 1591 roku (1996).

Większość publikacji Profesora oscylowała wokół tematyki XVI-wiecznej, choć wśród Jego książek znalazły się również pozycje z innego kręgu tematycznego. Jest autorem książki Słownictwo i frazeologia polskiej publicystyki okresu Oświecenia i Romantyzmu (1961), a w wydanym przez Adama Wolnikowskiego i Polskie Towarzystwo Historyczne Inwentarzu starostwa grudziądzkiego $z$ r. 1739 czuwał nad poprawnością wydanego tekstu.

Również w drobniejszych publikacjach przybliżał zarówno problematykę i teksty XVI-wieczne, jak również tematykę późniejszych okresów, np.: „,Vitae regum Polonorum" Klemensa Janickiego w przekładzie Jana Achacego Kmity (1980), Zróżnicowanie leksykalne i stylistyczne w „Poczcie Królewieckiej” z lat 1718-1720 (1990), Odbicie sporów teologicznych o dogmat Trójcy Świętej w polszczyźnie XVI w. (2003), Formacje odczasownikowe z przed- w polszczyźnie XVI wieku (2003). Poświęcił kilka artykułów postaci Profesora Konrada Górskiego oraz jego zainteresowaniom naukowym, m.in.: Profesor Konrad Górski jako badacz języka polskiego (w 90 rocznicę urodzin) (1986), Zainteresowania językoznawcze profesora Konrada Górskiego (1995), Stownik mickiewiczowski - dzieło życia profesora Konrada Górskiego (1995). Jako doświadczony leksykograf zabierał głos na temat dawnych słowników lub publikacji im poświęconym, np. w recenzji pt. O źródłach „Słownika” J. S. Bandtkiego (1987) dotyczacej Stownika dokładnego języka polskiego i niemieckiego do podręcznego używania dla Polaków i Niemców ułożonego (1806) autorstwa Jerzego Samuela Bandtkiego oraz recenzji z 1995 r. Kalendarza życia i twórczości Samuela Bogumiła Lindego (1992) Mariana Ptaszyka. Dla ,Zapisek Historycznych" w 2007 r. zrecenzował Profesor wydane przez Edmunda Kizika Nicolausa Volckmara Viertzig - Dialogi 1612. Źródto do badań nad życiem codziennym w dawnym Gdańsku (2005). 
Wyrazem uznania dla Jego dorobku i pozycji są przyznane medale i odznaczenia. Otrzymał dwa Medale ku Czci 100 Rocznicy Śmierci Adama Mickiewicza - polski i włoski, Medal ku Czci Samuela Bogumiła Lindego, Odznakę 1000-lecia Państwa Polskiego, Medal 30-lecia PRL, Medal Brązowy 100-lecia Towarzystwa Naukowego w Toruniu, Medal 25-lecia PAN, a także Złoty Krzyż Zasługi (1984). Pozostał przy tym człowiekiem skromnym i niezabiegającym o zaszczyty.

Profesor Franciszek Pepłowski całe swoje naukowe życie poświęcił żmudnej, drobiazgowej pracy badacza leksykografa. Dzięki Jego wszechstronnej wiedzy i zainteresowaniom, ale także wysiłkowi, olbrzymiej pracy i uporowi wydane zostały 32 tomy Słownika polszczyzny XVI wieku, obejmujące tysiące haseł od A do przodujący, czuwał również nad przygotowaniem kolejnych tomów do druku. Będziemy go pamiętać jako Człowieka niezwykle pracowitego i obowiązkowego, do końca pogrążonego w rozwikływaniu meandrów XVI-wiecznej leksyki i stylistyki. Zwykle można Go było spotkać skupionego na rozwiązywaniu codziennych problemów słownikarza w gabinecie toruńskiej pracowni. Jak sam kiedyś wyznał: „Praca przy słowniku ma i tę dobrą stronę, zarówno w ubiegłych latach, jak i teraz, że zaangażowanie w tę robotę pozwala zapomnieć o otaczającej nas rzeczywistości. To dobra ucieczka, azyl wewnętrzny"1. Drugą wielką pasją tego pracowitego Człowieka było pszczelarstwo. Jak mawiał, przy pracowitych pszczołach szukał wyciszenia, uciekał od codziennego zgiełku i koił nerwy. Również tej pasji Profesor pozostał wierny do końca życia.

Anetta Luto-Kamińska (Toruń)

1 Fragment wywiadu Słownik na całe życie, udzielonego przez Profesora 29 listopada 1996 r. toruńskim Nowościom (s. 8). 